\title{
Satellite-based modeling of permafrost temperatures in a tundra lowland landscape
}

\author{
Moritz Langer ${ }^{\mathrm{a}}$, Sebastian Westermann ${ }^{\mathrm{b}}$, Max Heikenfeld ${ }^{\mathrm{a}}$, Wolfgang \\ Dorn $^{\mathrm{a}}$, Julia Boike ${ }^{\mathrm{a}}$ \\ ${ }^{a}$ Alfred Wegener Institute for Polar and Marine Research, Potsdam, Germany \\ ${ }^{b}$ Institute of Geography, University of Oslo, Oslo, Norway
}

\begin{abstract}
Remote sensing offers great potential for detecting changes of the thermal state of permafrost and active layer dynamics in the context of Arctic warming. This study presents a comprehensive feasibility analysis of satellite-based permafrost modeling for a typical lowland tundra landscape in the Lena River Delta, Siberia. We assessed the performance of a transient permafrost model which is forced by time series of land surface temperatures (LSTs) and snow water equivalents (SWEs) obtained from MODIS and GlobSnow products. Both the satellite products and the model output were evaluated on the basis of long-term field measurements from the Samoylov permafrost observatory. The model was found to successfully reproduce the evolution of the permafrost temperature and freeze-thaw dynamics when calibrated with ground measurements. Monte-Carlo simulations were performed in order to evaluate the impact of inaccuracies and in model forcing and uncertainties in the parameterization. The sensitivity analysis showed that a correct SWE forcing and parameterization of the snow's thermal properties are essential for reliable permafrost modeling. In the worst case, the bias in the modeled permafrost temperatures can amount to $5{ }^{\circ} \mathrm{C}$. For the thaw depth, a maximum uncertainty of about $\pm 15 \mathrm{~cm}$ is found due to possible uncertainties in the soil composition.
\end{abstract}

Keywords: Permafrost modeling, Thermal state of permafrost, Thaw depth, MODIS, Land surface temperature, GlobSnow 


\section{Introduction}

Satellite-based earth observation has become an indispensable tool for the investigation of climate change especially in remote areas such as the Polar regions (Hall, 1988). For most of the cryosphere components such as glaciers, ice sheets, sea ice, and snow cover satellite monitoring and change detection has been established for several decades (e.g. Stroeve et al., 2007; Armstrong and Brodzik, 2001; Rignot and Thomas, 2002). Although permafrost is one of the largest components of the Arctic cryosphere, satellite-based monitoring schemes do not exist. Nevertheless, numerous ecosystem processes of the Arctic are directly or indirectly related to the thermal state of permafrost and the freeze-thaw dynamics of the upper most soil (active) layer (Van Everdingen, 1998). This is especially true for the energy, water, and carbon cycles which are strongly determined by sub-surface processes that often operate on spatial scales below the grid spacing of atmospheric models (Wania et al., 2009a,b). If satellite-based permafrost monitoring can provide an improved spatial resolution, this would strongly improve the impact assessment of climate change in the Arctic (ACIA, 2004; AMAP, 2011). In addition, an operational scheme could be beneficial for risk analysis for infrastructure such as roads, pipelines, and buildings which are directly affected by the thermal stability of permafrost (Larsen et al., 2008).

One of the biggest challenges is that permafrost is a subsurface thermal phenomenon which cannot be directly observed by remote sensing techniques. Thus, current approaches of permafrost monitoring make use of surface indicators such as vegetation cover (Stow et al., 2004), geomorphological units, or combinations of different surface features (Panda et al., 2010) in order to infer information about the permafrost conditions. However, these methods can only provide a qualitative measure of the thermal state of permafrost and changes are only detected when there is an impact on the surface. The application of land surface temperature (LST) records measured by satellites such as MODIS in order to retrieve freeze-thaw degree days is proposed by Hachem et al. (2009). In principle, such LST time series can be used to force a transient permafrost model that is able to reproduce the full thermal dynamics of the ground as proposed by Marchenko et al. (2009). Further studies suggest that the quality as well as the spatial and temporal resolution of MODIS LST products would be sufficient for permafrost modeling in non-mountainous terrain (Langer et al., 2010; Westermann et al., 2011b). However, model approaches are always subject to numerous assumptions, 
limitations, and uncertainties resulting from e.g. neglected processes and uncertainties in the forcing data or parameter settings (Boike et al., 2012b). Especially the soil and snow properties such as water/ice content, thermal conductivity, heat capacity, and density are usually unknown which introduce large uncertainties in heat flow calculations (e.g. Goodrich, 1982; Rinke et al., 2008; Gouttevin et al., 2012).

This study provides a proof-of-concept for a satellite-based permafrost monitoring and assesses its performance for a typical low land tundra site in NE Siberia. We (i) perform a thorough validation for the employed satellite data at the study site, (ii) present a thermal permafrost model forced by satellite data that delivers soil temperature and thaw depth, and (iii) evaluate the performance of the scheme and provide a sensitivity analysis for uncertain model parameters and inaccurate forcing data.

\section{Validation site}

The study site is located in Northern Siberia on Samoylov Island $\left(72.4^{\circ} \mathrm{N}\right.$; $126.5^{\circ} \mathrm{E}$ ) in the Lena-River Delta (Fig. 1). The local climate is described as arctic-continental with a mean annual air temperature (MAAT) of about $-13^{\circ} \mathrm{C}$ and a large annual air temperature amplitude ranging from about $-45^{\circ} \mathrm{C}$ in winter to $20^{\circ} \mathrm{C}$ in summer (Boike et al., 2012a). The total annual precipitation is about $200 \mathrm{~mm}$ of which about $25 \%$ falls as snow during winter (Boike et al., 2008; Langer et al., 2011a). The polar night lasts from the mid of November to end of January and polar day lasts from the beginning of May until the beginning of August. Samoylov Island features a typical tundra landscape underlain by continuous permafrost. The permafrost reaches depths of about $200 \mathrm{~m}$ (Grigoriev, 1960) and features relatively cold temperatures of about $-9{ }^{\circ} \mathrm{C}$ at the depth of zero annual amplitude $(20 \mathrm{~m})$ (Boike et al., 2012b). However, temperature observations indicate strong changes in the thermal state of permafrost which shows a steady warming of about $1^{\circ} \mathrm{C}$ between 2006 and 2011 at a depth of about $10 \mathrm{~m}$ (Boike et al., 2012a).

Samoylov Island belongs to an alluvial river terrace (Schwamborn et al., 2002) elevated about $20 \mathrm{~m}$ above the normal river water level. The lower western part of the island constitutes a modern floodplain which is frequently flooded during ice break-up of the Lena River during spring. The validation site of this study is located on the elevated river terrace mainly characterized by moss and sedge vegetated tundra (Fig. 1). In addition, several lakes and ponds occur which make up about $25 \%$ of the surface area of Samoylov Is- 
land (Muster et al., 2012). The land surface of the island features the typical micro-relief of polygonal patterned ground caused by frost cracking and subsequent ice-wedge formation (Lachenbruch, 1962). The polygonal structures usually consist of depressed centers which are surrounded by elevated rims. The polygonal structures often occur in different stages of degradation with partly to completely collapsed rims. The soil in the polygonal centers usually consists of water saturated sandy peat with the water table standing close to or above the surface (Langer et al., 2011a). The elevated rims are usually covered with a dry moss layer underlain by wet sandy peat soils featuring massive ice wedges. The volumetric water/ice content of the peat soils typically ranges from 60 to $80 \%$. The volumetric mineral content is reported to range from 20 to $40 \%$ while the volumetric organic content is on the order of 5 to $10 \%$ (Kutzbach et al., 2004; Zubrzycki et al., 2012). This cryogenic soil complex reaches depth of 10 to $15 \mathrm{~m}$ and is underlain by sandy to silty river deposits. The Lena River deposits are reported to reach depths of at least $1 \mathrm{~km}$ in the delta region (Grigoriev et al., 1996).

\section{Methods}

\subsection{Model description}

This study makes use of a 1D soil heat transfer model capable of representing the freeze-thaw cycle and a dynamic snow cover formation and ablation. The model is based on solving the heat transfer equation including a term which accounts for the phase change of soil water (Yershov, 1998),

$$
\left(C_{\mathrm{h}}+\rho_{\mathrm{w}} L_{\mathrm{sl}} \frac{\partial \Theta_{\mathrm{w}}}{\partial T}\right) \frac{\partial T}{\partial t}-\frac{\partial}{\partial z}\left(K_{\mathrm{h}} \frac{\partial T}{\partial z}\right)=0,
$$

where $T$ is the soil temperature, $C_{\mathrm{h}}$ the volumetric soil heat capacity and $K_{\mathrm{h}}$ the soil thermal conductivity. $\frac{\partial \Theta_{\mathrm{w}}}{\partial T}$ is the change of liquid soil water content with temperature which in combination with the latent heat of fusion $L_{\mathrm{sl}}$ and the density of water $\rho_{\mathrm{w}}$ gives the rate of energy turnover related to soil water phase change. The volumetric soil heat capacity $C_{\mathrm{h}}$ can be calculated as sum of heat capacities of each soil component $C_{\mathrm{j}}$ weighted by its volumetric fraction $\Theta_{j}$

$$
C_{\mathrm{h}}=\sum_{\mathrm{j}} \Theta_{\mathrm{j}} C_{\mathrm{j}}
$$

where $\mathrm{j}$ represents each soil component (ice, water, mineral, and organic). The soil thermal conductivity $K_{\mathrm{h}}$ is based on a modified version of the 
deVries-model (De Vries, 1952) applicable in frozen or partly frozen soils, which has been successfully employed in permafrost modeling (Westermann et al., 2011a; Weismüller et al., 2011). The soil heat conductivity $K_{\mathrm{h}}$ is then calculated as

$$
K_{\mathrm{h}}=\frac{\sum_{\mathrm{j}} \Theta_{\mathrm{j}} f_{\mathrm{j}} K_{\mathrm{j}}}{\sum_{\mathrm{j}} \Theta_{\mathrm{j}} f_{\mathrm{j}}},
$$

where $f_{\mathrm{j}}$ summaries soil specific parameters including shape factors for soil particles and threshold values for soil water circulation. A more detailed description of the parameterization can be found in Campbell et al. (1994). The volumetric content of liquid soil water with temperature $\Theta_{\mathrm{w}}(T)$ is the freeze curve of the soil and strongly depends on soil composition and structure. This soil specific freeze curve can be parametrized by a second order polynomial as

$$
\Theta_{\mathrm{w}}(T)=\left\{\begin{array}{ll}
\Theta_{\mathrm{w}(\min )}+\frac{\Theta_{\mathrm{w}(\max )}-\Theta_{\mathrm{w}(\min )}}{1-a T+b T^{2}} & \text { for } T<0 \\
\Theta_{\mathrm{w}(\max )} & \text { for } T \geq 0
\end{array},\right.
$$

where $a$ and $b$ are empirical factors, whereas $\Theta_{\mathrm{w}(\max )}$ and $\Theta_{\mathrm{w}(\min )}$ are the maximum and minimum liquid water content, respectively.

For the numerical solution of the model, the heat transfer equation (Eq. 1) is discretized spatially with finite differences. The time derivatives are solved using an ordinary differential equation solver (ode15s) provided by MATLAB which uses a self-adaptive time integrator and is well suited for stiff problems (Shampine and Reichelt, 1997).

\subsection{Model setting, boundary conditions, and initialization}

The model is solved on a soil domain ranging from 0 to $600 \mathrm{~m}$ depth containing 104 vertical grid cells. The size of the grid cells increases with depths with a minimum grid cell spacing of $2 \mathrm{~cm}$ at the surface and maximum spacing of $20 \mathrm{~m}$ at the bottom. The uppermost soil layer can take any soil composition, whereas the ground below $20 \mathrm{~m}$ depth is assumed to consist of fluvial sediments with uniform composition (cp. Sect. 2). Following literature values for sandy river deposits, the composition of the fluvial sediments is set to a mineral soil with $20 \%$ pore space which is fully saturated by water or ice (Boike et al., 2012a). The compositions of the soil grid cells between the variable surface layer and the static deep soil layers are linearly interpolated. Note that the applied model is limited to heat transfer in soils. Hence, the thermal dynamics underneath water bodies such as lakes is not represented 
in the applied scheme. An additional layer of 60 grid cells with a constant grid cell spacing of $2 \mathrm{~cm}$ is stacked on top of the soil domain to represent the snow cover. The model is forced at the upper boundary by the land surface temperature LST where the surface is defined as the soil-atmosphere or the snow-atmosphere interface, respectively. As snow depth changes over time, the location of the upper boundary can be shifted dynamically on the snow grid (more detailed description in Westermann et al. (2011a)). For simplicity, the snow cover is treated as an effective snow cover with uniform and constant properties over depth and the entire simulation period. Following Goodrich (1982) the volumetric heat capacity of snow is calculated from the snow density $\rho_{\mathrm{s}}$ as

$$
C_{\mathrm{s}}=2.09 \times 10^{3} \rho_{\mathrm{s}} .
$$

At the lower boundary of the soil domain, a constant geothermal heat flux $Q_{\text {geo }}$ is applied. Global heat flow data are available through the International Heat Flow Commission (IHFC) (Pollack et al., 1993). We apply the geothermal heat flux value of $0.053 \mathrm{Wm}^{-2}$ which is measured in a $600 \mathrm{~m}$ borehole close to Tiksi located about $140 \mathrm{~km}$ east of our field site.

\subsection{Model forcing}

The forcing dataset consists of a synthesized time series of land surface temperatures (LST) and snow water equivalents (SWE) (Fig. 2). The entire forcing dataset covers a period from 1982 to 2011 which is divided into a target period ranging from 2002 to 2011 and a spin-up period from 1982 to 2001. During the target period, the forcing of the permafrost model is exclusively based on remote sensing data including the MODIS LST, MODIS snow cover fraction (SFC), and GlobSnow SWE products. The spin-up of the model starts from an initial temperature field of the soil domain which is calculated assuming steady state heat flow with a constant average soil surface temperature $T_{0(\text { av }}$. The 20 year spin-up period allows to start with a transient temperatures distribution down to a depth of the approximately $20 \mathrm{~m}$. During the spin-up period, the surface temperature forcing is obtained from ERA-Interim reanalysis data, whereas SWE data are obtained from GlobSnow.

\subsubsection{Surface temperature}

During the spin-up period (1982-2001) satellite-based land surface temperature (LST) measurements from MODIS are not available. Therefore, 
the required surface temperature forcing is extracted from the ERA-Interim reanalysis product provided by the European Centre for Medium-Range Weather Forecasts (ECWMF). The ERA-Interim product contains the full set of forecast and analyzed fields of a numerical weather model within which numerous meteorological observations are assimilated (Dee et al., 2011). The reanalysis product provides four time daily gridded surface temperatures since 1979 with a spatial resolution of $0.5^{\circ}$. The ERA-Interim product is extensively validated and found to be in good agreement with meteorological observations (e.g. Simmons et al., 2010; Szczypta et al., 2011; Mooney et al., 2011). In contrast to the earlier version ERA-40, ERA-Interim is reported to provide reliable temperature values in the Arctic (Screen and Simmonds, 2011). The coarse scale surface temperature values of the reanalysis product are interpolated to the location of the study site using bicubic interpolation.

During the target period (2002-2011) the surface temperature forcing is based on the MODIS L3 collection 5 LST products MOD11A1 (Terra) and MYD11A1 (Aqua) with a spatial resolution of $1 \mathrm{~km}$. The used LST products contain day- and night-time surface temperatures which are obtained and radiometrically corrected by the generalized split window approach (Wan and Dozier, 1996). From the daily tiles a time series of daily LST averages is compiled for the pixel encompassing the validation site. Frequent data gaps occur due to clouds resulting in a clustered time series with an overall data availability of $68 \%$. The clustered LST time series leads to a systematic over representation of surface temperatures during clear sky conditions which can cause a cold bias during winter (Westermann et al., 2012). A number of studies have addressed the difficulties associated with clustered LST data when used to derive long-term LST averages (Hachem et al., 2009; Langer et al., 2010; Westermann et al., 2011b). However, missing data are filled by linear interpolation in order to obtain a continuous data record from which weekly LST averages are inferred. In addition to overrepresented clear sky LST values, erroneously measured cloud top temperatures can cause a cold-bias in the LST averages during summer and winter (Liu et al., 2010; Westermann et al., 2012). Despite the admixture of free water surfaces within the MODIS pixel, the obtained LST data are considered to represent the surface temperature of the land or the snow cover as appropriate. The fraction of free water surface within the MODIS pixel is approximately $25 \%$ (cp. Sect. 2). In addition, strong sub-resolution land surface heterogeneities can occur during the snow melt period due to persistent snow patches (Westermann et al., 2011b). However, field observations indicate that this period is relatively short $(2-3$ 
weeks) at the study site.

\subsubsection{Snow cover}

The GlobSnow product provides longterm data on snow water equivalent (SWE) and snow extent (SE) across the northern hemisphere since 1979. GlobSnow is a hybrid product which assimilates passive microwave satellite measurements, as well as records from climate stations to derive daily SWE maps with a spatial resolution of $25 \mathrm{~km}$ (Takala et al., 2011). The SWE retrieval algorithm has been developed and validated by the Finnish Meteorological Institute (FMI) for various tundra and alpine landscapes (Luojus et al., 2010). The average error of the GlobSnow SWE product is reported to be less than $35 \mathrm{~mm}$ and even smaller for tundra landscapes. However, extensive field studies demonstrate that passive microwave SWE detection is subject to large uncertainties mainly introduced by the snow morphology, vegetation cover, and the presence of white (refrozen and bubble rich) ice on lakes and rivers (Foster et al., 2005; Derksen et al., 2005, 2011). Largest retrieval errors are reported to occur during snow cover accumulation and melt. A comprehensive overview on satellite based snow cover monitoring and the potential error sources is given by Frei et al. (2012). The grid cell containing the validation site contains approximately $60 \%$ land surfaces similar to that of the validation site, $20 \%$ river arms, and $20 \%$ floodplains. Despite this sub-resolution landscape heterogeneity, the grid cell is considered representative for the validation site. This is especially critical during snow fall and snow melt when large spatial differences in snow cover can occur between the different landscape units.

In order to reduce the discrepancies in spatial resolution between MODIS LST $(1 \mathrm{~km})$ and GlobSnow SWE $(25 \mathrm{~km})$, additional snow cover information is obtained from the MODIS snow cover products (MOD10A1, MYD10A1). Among other information, the tiles contain daily snow cover fractions (SCF) at a spatial resolution of $500 \mathrm{~m}$. The satellite data are available during the entire target period (2002-2011) and are provided by the National Snow and Ice Data Center (NSIDC) (Hall and Riggs, 2007). The MODIS snow cover detection algorithm is based on the Normalized Difference Snow Index (NDSI) including a consistency check based on the surface temperature (Hall et al., 2002). The MODIS snow product is extensively validated for different landscape types (e.g. Salomonson and Appel, 2004; Stroeve et al., 2006; Hall et al., 2009). Similar to the LST product, uncertainties are introduced by erroneous cloud detections which potentially leads to data loss and overesti- 
mated SCF values (Hall and Riggs, 2007). Data gaps due to clouds are filled by linear interpolation and weekly SCF averages are compiled afterwards. The MODIS SCF product provides high-resolution data on timing of snow cover build-up and disappearance. These additional information are used to enhance the GlobSnow SWE product which is subject to errors especially during the snow accumulation and ablation periods. A stable snow cover is expected to occur when two consecutive weeks feature snow cover fractions of larger than 10\%. GlobSnow SWE values are set to zero when the stable snow cover criterium is not fulfilled. Conversely, linear interpolation between the onset of a stable snow cover and the first non-zero SWE value is applied when a stable snow cover is indicated by MODIS SCF but not by GlobSnow SWE. The enhanced SWE time series is validated by SWE field observations and continuous snow depth measurements at the validation site (cp. Sect. 3.4).

\subsection{Validation data sets}

All forcing data are validated by surface temperature and snow depth measurements at the study site which are continuously available since 2002 . The surface temperatures are calculated from measurements of a down facing long wave radiation sensor (CG1, Kipp \& Zonen, Netherlands). The out going long wave radiation is converted to surface temperature by using Stefan-Boltzmann law assuming the surface emissivity to be unity. Under specific meteorological conditions this simplification can lead to overestimated surface temperatures (Westermann et al., 2011b). However, it is the best available estimate on the radiometric surface temperature as measured by MODIS and calculated by ERA-Interim. Snow depth measurements for a point on Samoylov Island are performed by an ultra sonic ranging sensor (SR50, Campbell Scientific, USA) located close to the surface temperature measurements.

The performance of the model is validated by comparing the simulated soil temperatures to a 5 year record of ground temperatures measured in a borehole in $2.5 \mathrm{~m}$ and $11 \mathrm{~m}$ depth. The borehole is located close to the meteorological station. The area around the borehole is characterized by low centered polygons featuring dry rims and wet centers (cp. Sect.2). Within a distance of more than $100 \mathrm{~m}$ only two polygonal ponds occur with surface areas less than $80 \mathrm{~m}^{2}$. The borehole is equipped with a temperature chain (XR-420, RBR Ltd., Canada) which features an absolute accuracy of about $0.05^{\circ} \mathrm{C}$. The validation depths are well suited to investigate the model performance for the annual temperature cycle and the longterm temperature 
evolution. The borehole temperatures have been recorded with $1 \mathrm{~h}$ resolution since July 2006. In addition, manual thaw depth measurements are used in order to validate the modeled thaw dynamics. Thaw depth measurements have been performed since 2002 on a weekly basis on a $500 \mathrm{~m}^{2}$ plot consisting of a regular grid of 150 measurement points. The thaw depth is measured relative to the surface using a metal rod. These measurements are consistently available throughout the end of July, which is therefore used as reference date for the thaw depth validation. Prior to the model validation all required parameters are obtained by fitting the model to the borehole temperature measurements. This set of parameters is also used as midpoint for the following Monte-Carlo simulations (cp. Sect. 3.5).

\subsection{Monte-Carlo simulations}

Monte-Carlo simulations are performed in order to evaluate the sensitivity of the permafrost model to (i) uncertainties in the selected model parameters (in particular soil and snow thermal parameters) and (ii) inaccuracies in the forcing data. The uncertainties and the inaccuracies propagate through the model and result in uncertainties in the simulated soil temperatures and thaw depths. Different magnitudes and combinations of uncertainty ranges and accuracy levels are evaluated based on 24 Monte-Carlo simulations (cp. Tab. A.1) each of which involves 500 model realizations. For each model realization, random variations in model forcing or parameterization are generated for the respective accuracy level and uncertainty class. The generation of the random values follows a uniform probability distribution.

In a first series of simulations, only the uncertainties which are introduced by the model parameterization are considered (Tab. A.1). We assume different classes of uncertainty, in following denoted high, intermediate, and low uncertainty. The parameters are grouped into three categories (snow, soil, and initialization). We distinguish the following Monte-Carlo simulations: High, intermediate, and low uncertainty for all parameter categories (MCp1), high uncertainty for two of the categories and high, intermediate, and low uncertainty for the remaining category (MCp2-4). This procedure is applied in order to explore how much the output uncertainty can be reduced by enhancing the knowledge of a single parameter group. The assumed high uncertainty class for the snow parameters is in accordance with reported variabilities of snow properties in the Arctic as summarized by Sturm et al. (1997). Note that the thermal conductivity and density of the snow cover are considered to be independent from each other in the specified ranges of 
uncertainty. This assumption is made in order to represent the full range of thermal conductivities $\left(0.03-0.2 \mathrm{Wm}^{-1} \mathrm{~K}^{-1}\right)$ that is reported for densities between 200 and $300 \mathrm{kgm}^{-3}$ (Sturm et al., 1997). The high uncertainty class assumed for the initial surface temperature $T_{0(\text { av })}$ equates to the variance of the annual average surface temperature between 1979 and 1982 obtained from the ERA-Interim dataset. The assumed variation of the freeze curve covers a wide range of freeze characteristics from sandy to silty soils, as suggested by field observations (Langer et al., 2011b). The high uncertainty class of the soil components is assumed to realistically represent the potential variability of low land tundra soils which can range from medium-dry organic soils to water/ice saturated mineral soils (Boike et al., 2012a). For the soil constituents, uniform probability distributions have been chosen with the constraint, that the sum of all is unity. According to the applied conductivity model (cp. Sect. 3.1), the uncertainties in soil composition correspond to uncertainties in soil thermal conductivity (unfrozen soil) of about $\pm 0.33 \mathrm{Wm}^{-1} \mathrm{~K}^{-1}$ for the high uncertainty class, $\pm 0.2 \mathrm{Wm}^{-1} \mathrm{~K}^{-1}$ for the intermediate uncertainty class, and $\pm 0.15 \mathrm{Wm}^{-1} \mathrm{~K}^{-1}$ for the low uncertainty class. The uncertainties in heat capacity are $\pm 0.8 \mathrm{MJm}^{-3}, \pm 0.4 \mathrm{MJm}^{-3}$, and $\pm 0.2 \mathrm{MJm}^{-3}$ respectively. In frozen state, the uncertainties in thermal conductivity are more than doubled. In contrast, the uncertainties in heat capacity are almost three times smaller than in unfrozen state. In general, the uncertainties in the soil thermal properties decrease with depth as the varying soil composition at the surface is linearly interpolated to a fixed composition in $20 \mathrm{~m}$ depth (cp. Sect. 3.2).

The impact of inaccuracies in the LST and SWE forcing data on the model results are considered in similar manner as for the parameterization (Tab. A.1). The assumed low accuracy levels are in accordance with reported accuracies for the data products (cp. Sect.3.3). The accuracy of the forcing data is then stepwise enhanced by a factor of two for the intermediate and the high accuracy simulations. At first, the accuracies are enhanced for both forcing datasets (LST and SWE) simultaneously (MCf1) and later for LST and SWE individually (MCf2-3). In contrast to the settings for the parameterization, the inaccuracy of the currently unprocessed forcing dataset is set to zero. The inaccuracies in the SWE forcing do not affect the duration of the snow cover which is considered to be accurately detected by the satellite products. Hence, a minimum snow cover of $2 \mathrm{~cm}$ (corresponding to one snow grid cell) is assumed when a snow cover is indicated by MODIS SCF but not by GlobSnow SWE. 


\section{Results}

\subsection{Validation of the forcing data}

Daily and weekly surface temperature values from MODIS LST and ERAInterim are compared with surface temperature averages obtained by radiometric measurements at the Samoylov field site (Fig. 3). Despite a spread of about $5{ }^{\circ} \mathrm{C}$, there is a coherent relationship between the field measurements and the MODIS data over the entire temperature range from -50 to $+20^{\circ} \mathrm{C}$. The data are mostly well centered around the 1:1 line. On average, the temperature deviations between the MODIS LST data and the observations is about $\pm 2{ }^{\circ} \mathrm{C}$ which equates to an accuracy of about $3 \%$ relative to the entire temperature range. However, at surface temperatures between -10 and $10^{\circ} \mathrm{C}$ numerous outliers are observed. The outliers are consistently negative and feature temperature offsets of up to $20^{\circ} \mathrm{C}$. The ERA-Interim surface temperatures show a lower spread in the range from -20 to $20^{\circ} \mathrm{C}$. However, under very cold conditions (below $-20^{\circ} \mathrm{C}$ ) the reanalysis product shows a steadily increasing cold bias which reaches a maximum offset of about $10^{\circ} \mathrm{C}$ at surface temperatures of about $-40^{\circ} \mathrm{C}$. From daily MODIS LST values, weekly averages are generated after the gap filling procedure (cp. Sect. 3.3.1). The outliers around the freezing point disappear after averaging, but a slight cold bias of about $2{ }^{\circ} \mathrm{C}$ emerges. The agreement between ERA-Interim and field observations increases for weekly averages, but the characteristic temperature bias below $-20^{\circ} \mathrm{C}$ remains. However, extremely low surface temperatures only occur occasionally so that temperature offsets larger than $5^{\circ} \mathrm{C}$ are very rare.

The applied model scheme assumes constant and uniform snow properties so that GlobSnow SWE data can be directly assigned to snow depths via the snow density (cp. Sect. 3.3.2). A snow density of approximately $250 \mathrm{~kg} \mathrm{~m}^{-3}$ is found by the fitting procedure (cp. Sect. 3.4) by which the evolution of snow depth can be relatively well reproduced (Fig. 4). The fitted snow density is well within the range of snow density measurements performed at the same study site (Boike et al., 2012a). Using a constant snow density as a first order approximation, the satellite data tend to underestimate snow depths when the snow cover is relatively thick. However, differences in snow depth between field observations and satellite data are in $90 \%$ of cases less than $5 \mathrm{~cm}$. This equates to a SWE accuracy of $\pm 13 \mathrm{~mm}$ if a constant snow density is applicable to the study site. Relative to the entire SWE range $(0-150 \mathrm{~mm})$ at the study site, this corresponds to a relative accuracy of about $10 \%$. Note 
that a satellite product with a resolution of $25 \mathrm{~km}$ is compared to snow depth measurements at a specific point and a perfect match can not be expected since spatial snow cover differences are very likely due to wind drift and micro topographic variations within the satellite footprint. In most cases, the applied correction based on the MODIS SCF product leads to a slightly better reproduction of the onset of snow accumulation. The uncorrected GlobSnow data often show a delayed snow cover build up on the order of about two weeks. In a few occasions, the MODIS SCF correction leads to an earlier snow cover build up. In contrast to snow cover build up, the timing of snow melt is consistent between the GlobSnow and the MODIS product so that a correction does not occur. In general, the timing of snow melt is well reproduced by the satellite data.

\subsection{Model performance and uncertainty}

The model performance with regard to temperature is shown in Fig. 5 for soil depths of 2.5 and $11 \mathrm{~m}$. The solid line indicates the result of the best parameter setting found after the fitting procedure (cp. Sect. 3.4). At a depth of $2.5 \mathrm{~m}$ the general magnitude of the annual temperature dynamics can be relatively well reproduced. However, a constant cold bias of about $-1^{\circ} \mathrm{C}$ is found for the best fit results during summer. During winter, the temperature differences between the model results and the borehole measurements can be as large as $2{ }^{\circ} \mathrm{C}$, but strongly vary in magnitude and sign. After winter, a short delay in the rewarming of the soil occurs in the simulations. However, the timing of soil cooling after summer is mostly in good agreement with the observations. Compared to the measurements, the simulated temperatures in $11 \mathrm{~m}$ depth are slightly too cold. The temperature offset increases from about 0.5 to $1^{\circ} \mathrm{C}$ with the largest temperature differences during summer. Hence, the measured soil warming exceeds the simulations, but the model reproduces a general soil warming over the entire target period. Fig. 5 also displays the results of MCp1 (cp. Tab. 1) according to the prescribed classes for low, intermediate, and high uncertainty. An almost symmetric range of uncertainty around the median occurs around the best fit for the low uncertainty class. At $2.5 \mathrm{~m}$ depth the output uncertainty is about $\pm 1^{\circ} \mathrm{C}$ during summer and $\pm 3{ }^{\circ} \mathrm{C}$ during winter, whereas at $11 \mathrm{~m}$ depth the output uncertainty is almost constant at around $\pm 1{ }^{\circ} \mathrm{C}$. The width of the uncertainty range slightly increases over the target period. For the intermediate uncertainty class, the summertime temperature uncertainty remains almost centered around the best fit but the range increases to $\pm 2{ }^{\circ} \mathrm{C}$. In some oc- 
casions a slightly negative temperature shift of the uncertainty field can be observed. In contrast, a clear positive temperature shift occurs during winter so that the output uncertainty ranges with $-4^{\circ} \mathrm{C}$ and $+5{ }^{\circ} \mathrm{C}$ around the best fit. In fact, a constant positive shift of the uncertainty fields occurs at a depth of $11 \mathrm{~m}$ ranging with $-1.5^{\circ} \mathrm{C}$ and $+2{ }^{\circ} \mathrm{C}$ around the best fit. As in the previous uncertainty class, the width of the uncertainty range slightly increases over the target period. In the high uncertainty class, the output uncertainty strongly increases. At $2.5 \mathrm{~m}$ depth the uncertainty spreads around the best fit with $-3{ }^{\circ} \mathrm{C}$ and $+2{ }^{\circ} \mathrm{C}$ during summer and $-3{ }^{\circ} \mathrm{C}$ and $+13^{\circ} \mathrm{C}$ during winter. The strong deviation is attributed to a strongly delayed refreezing of the active layer. At a depth of $11 \mathrm{~m}$ the uncertainty field ranges with $-2{ }^{\circ} \mathrm{C}$ and $+4.5^{\circ} \mathrm{C}$ around the best fit at the beginning of the target period. The upper limit of the uncertainty range increases by about $0.5^{\circ} \mathrm{C}$ while the lower limit stays almost constant in the course of the target period. In both depths, the measured soil temperatures mostly stay within the limits of the low uncertainty class.

A comparison of measured and simulated thaw depths at the end of July is shown in Fig. 6. The thaw depth measurements show a large spatial scatter with a range of up to $30 \mathrm{~cm}$. In most years, the distribution of the thaw depth is symmetric with about $50 \%$ of the values located within half of the range. The simulated thaw depths for the best fit are always within the range of the measurements. The difference between the median of the thaw depth measurements and the simulated (best fit) thaw depth is in most cases lower than $10 \mathrm{~cm}$. The model usually tends to overestimate thaw depths. However, main features of the inter-annual thaw dynamics are to some extent reproduced by the model. In particular, the relatively large thaw depth in 2005 which decreases again in 2006 and the comparatively low thaw depth 2009 followed by a sharp increase in 2010. With low input uncertainty, the resulting thaw depth uncertainty is smaller than $\pm 5 \mathrm{~cm}$. The uncertainty bar is usually centered around the best fit. In some cases, however, the best fit is located at the upper edge of the uncertainty range. Since only completely thawed soil grid cells are considered in the uncertainty analysis, it is possible that the upper limit of the uncertainty range is underestimated at maximum by $2 \mathrm{~cm}$. With intermediate input uncertainty, the uncertainty in thaw depth increase to about $\pm 8 \mathrm{~cm}$ and reaches its maximum of about $\pm 15 \mathrm{~cm}$ in the high uncertainty class. The maximum uncertainty range agrees in magnitude with the observed thaw depth variability. In most cases, the uncertainty range is larger for years with deeper thaw depth. 


\subsection{Uncertainty due to model parameters}

As shown in Sect.4.2, the uncertainties of the input parameters lead to a large spread in the soil temperature calculations. The distributions of the average soil temperatures in $2.5 \mathrm{~m}$ and $11 \mathrm{~m}$ depth as revealed from the Monte-Carlo simulations are displayed in Fig. 7. In each MC simulation, the input uncertainty of one parameter group is stepwise reduced down to a fixed (best fit) value with zero uncertainty (cp. Sect.3.5). The temperature distributions at maximum uncertainty are similar for the different simulations indicating a sufficient number of model runs. Almost all simulations show positively skewed distributions in both depth with a stronger temperature spread in $2.5 \mathrm{~m}$ than in $11 \mathrm{~m}$ depth. The positive skewness indicates that strong temperature biases occur more frequently in positive than in negative direction which is attributed to the delayed refreezing caused by the phase change of soil water. The median of the high uncertainty class is located at about $-9.5^{\circ} \mathrm{C}$ for all simulations and both depth. This is about $0.5^{\circ} \mathrm{C}$ colder than expected from the best fit average. This negative bias from the expected best fit value is decreased by reducing the uncertainty in the soil parameters. For all other simulations the bias between the median and the best fit value remains. However, reducing the uncertainty in the soil parameters does not affect the spread of the distributions which stays almost constant. Conversely, lowering the uncertainty in the snow parameters leads to a strong reduction in the temperature spread. Furthermore, the simulations with reduced uncertainty in snow reveal a much lower skewness. The bias between soil temperature measurements and best fit simulation might still be explained by the lowest snow uncertainty. The temperature distribution becomes completely symmetrical when zero uncertainty for the snow parameters is assumed. However, a temperature spread of about $\pm 1{ }^{\circ} \mathrm{C}$ remains due to the uncertainties in the other parameter groups. Variations in the uncertainty of the initial conditions only show a minor impact on the resulting temperature distribution.

In summary, the results demonstrate that the uncertainties in modeled soil temperatures are most strongly determined by uncertainties in the snow parameters. Snow cover uncertainties not only control the temperature spread but also the shape of the distribution. The effect of the snow thermal conductivity on the thermal state of permafrost is much more pronounced than that of the snow density which controls heat capacity and depth of the snow cover. 
The sensitivity of the modeled thaw depths to uncertainties in the parameterization is exemplarily displayed for the year 2010 (Fig. 8). As discussed in Sect. 4.2, the maximum input uncertainty in the parameterization results in a thaw depth uncertainty of about $\pm 15 \mathrm{~cm}$. The thaw depth distributions are positively skewed with the median thaw depth about $5 \mathrm{~cm}$ lower than expected from the best fit. Reducing the uncertainty in the parameter groups reveals that the spread in thaw depth, the skewness of the distribution, as well as the bias between median and best fit result are entirely governed by the soil parameters. The snow cover as well as the initial surface temperature barely affect the simulated thaw depths. When the uncertainty of the soil parameters is reduced the uncertainty in thaw depth decreases almost proportional. However, a spread in thaw depths of about $+10 \mathrm{~cm}$ and $-5 \mathrm{~cm}$ remains even when the soil parameters are fixed at the best fit values. Under the given environmental conditions (external forcing, thermal state of the ground) the contribution of the freeze curve to the thaw depth uncertainty is almost negligible. The spread in the spatially distributed thaw depth measurements is almost similar to the spread of the modeled thaw depths. Hence, the variance of soil properties at the study site is well represented by the high uncertainty class.

\subsection{Uncertainty due to forcing data}

The sensitivities of the model to potential inaccuracies in the LST and SWE forcing data are illustrated in Fig. 9 and Fig. 10. Assuming a low accuracy in LST and SWE leads to a strong spread in the resulting temperature distributions in both depths (Fig. 9). In contrast to the temperature distributions which result from uncertainties in the parameterization, the distributions according to the different accuracies in the forcing data are almost uniform and centered around the best fit value. A stepwise enhancement of the accuracy by a factor of two leads to an almost proportional decrease in the temperature spread. However, the bias between the temperature measurements and the best fit simulation is within the margins of the high accuracy level. The spread of the temperature distribution strongly decreases when inaccuracies in the SWE data are neglected. Close to the surface $(2.5 \mathrm{~m})$, the observed temperature spread equates approximately to the corresponding LST accuracy. The temperature distribution at low LST accuracy reveals a positive skewness which disappears for the high accuracy level. The temperature spread caused be inaccuracies in LST decreases with depth $(11 \mathrm{~m})$ while the shape of the distributions remains the same. A similar behavior can 
be observed for the results of the SWE simulations. However, the resulting temperature spread is by a factor of four larger compared to the distributions obtained from the LST simulations. The bias between measured soil temperatures and the best fit simulation can be already explained with a high accuracy $( \pm 10 \mathrm{~mm})$ in the SWE forcing.

The uncertainty in the modeled thaw depth is less than $\pm 10 \mathrm{~cm}$ for the lowest accuracy level of the combined LST and SWE simulation (Fig. 10). For the higher accuracy levels, the uncertainty in thaw depth spreads only in negative direction. The median of the uncertainy distribution equates always to the thaw depth which is calculated in the best fit model run. The simulations show that inaccuracies in the SWE forcing only marginally contribute to the uncertainties in thaw depth.

\section{Discussion}

\subsection{Applicability of the forcing data}

Extensive validation of the MODIS LST data reveals that despite outliers and frequent data gaps a reliable forcing dataset of weekly surface temperatures can be generated from the satellite measurements. The observed quality of the MODIS LST data is comparable to accuracies reported for other polar regions (Koenig and Hall, 2010; Hachem et al., 2012). Similar to a MODIS validation study performed on Svalbard (Westermann et al., 2012), a lower quality of the LST data is observed for temperatures around the freezing point. However, the general data quality seems to be better at our study site which is most likely related to the lower cloudiness because of the more continental climate conditions. Hence, it can be assumed that the quality of a surface temperature forcing generated from MODIS LST strongly varies in different climate regions. In addition to that, it must be assumed that the LST quality varies throughout the annual cycle. Without ground observation and validation, we estimate a maximum accuracy of $\pm 2{ }^{\circ} \mathrm{C}$ for the generated LST forcing. With such an LST accuracy, the thermal state of permafrost is reproduced within a range of +1.5 and $-1{ }^{\circ} \mathrm{C}$ in $11 \mathrm{~m}$ depth. The skewness of the simulated temperature range indicates that LST biases have a stronger impact in positive than in negative direction which is most likely caused by the thermal insulation of the snow cover and the delayed refreezing due to the phase change of soil water (Goodrich, 1982;

Romanovsky and Osterkamp, 2000; Smith et al., 2010). Inaccuracies in the LST forcing are especially critical during summer when they are not overlain 
by the inaccuracies in the SWE forcing or uncertainties in the snow cover parametrization. Hence, inaccuracies in the LST forcing directly affect the quality of thaw depth simulations. With an LST accuracy of $\pm 2{ }^{\circ} \mathrm{C}$ the thaw depth is reproduced with an uncertainty of about $\pm 3 \mathrm{~cm}$.

The SWE forcing generated from the GlobSnow and MODIS SCF products reproduces the evolution of the snow depth at the study site relatively well by assuming a constant snow density. The combination of both snow cover products provides a better reproduction of the onset of snow cover. Comparing the simulated and the measured soil temperatures reveals temperature differences especially during winter which are most likely attributed to a wrong representation of the insulating effect of the snow cover. This can result from either incorrect SWE forcing, or inappropriate snow parameterization, or a combination of both. The MC simulations reveal a very strong impact of SWE inaccuracies on the model performance. The highest accuracy level assumed in the MC simulations for the SWE forcing equates approximately to the observed accuracy after calibration of the snow density with field measurements (cp. Sect.4.1). The thermal state of permafrost is reproduced with an uncertainty of about $\pm 2.5^{\circ} \mathrm{C}$ with a SWE accuracy of about $\pm 10 \mathrm{~mm}$. This is still below the performance that can be reached with a realistic LST accuracy of about $\pm 2{ }^{\circ} \mathrm{C}$. However, a much lower SWE accuracy level $( \pm 40 \mathrm{~mm})$ must be considered in regions with sparse weather stations (Luojus et al., 2010) and when field measurements are not available for calibration. Our results show that realistic permafrost simulations with a transient heat transfer model would be almost impossible with such low accuracies in the SWE forcing. In contrast to the permafrost temperatures, the thaw depths are found to be more or less independent from the SWE accuracy. However, this might be different in regions where the permafrost temperature is already close to the freezing point as observed by Akerman and Johansson (2008). In any case, the impact of snow on the active layer dynamics can be very complex and dependent on regional factors (Zhang, 2005). The performed sensitivity study demonstrates that a highly accurate snow cover forcing is crucial for reliable permafrost modeling.

\subsection{Applicability of the model scheme}

The results of this study demonstrate that permafrost modeling in low land tundra based on remote sensing data is in principle possible, provided that a correct snow cover forcing is available. A fairly simple model scheme with very coarse approximations on soil strata, snow cover properties, and 
neglected soil water flow reasonably reproduces the temperature and freezethaw dynamics at the study site over a period of 5 years. In addition, the observed warming of deeper permafrost at the study site could be reproduced. Note that the borehole temperatures that are used for validation represent the specific thermal sate at one point of the study site which is unlikely to be exactly reproduced by the generalized soil parameterization of the model. Hence, it can not be expected that the model exactly reproduces the borehole measurements. However, the best fit result of this study is comparable in accuracy to other model studies which usually use in situ measurements as forcing data and feature more optimization possibilities due to a more complex parametrization (e.g. Jiang et al., 2012). The synthesized dataset of soil surface temperature and snow water equivalent has a reasonable quality in order to be used as forcing for a permafrost model (cp. Sect. 5.1). Despite the relatively good performance during summer, the applied scheme reveals shortcomings especially during the winter period. On one hand it is possible that the temperature mismatches between model and observations are attributed to inaccuracies in the SWE forcing (cp. Sect. 5.1), but on the other hand it is very likely that they are related to the static representation of the thermal snow properties. The applied scheme does not account for the natural dynamics of the snow cover which passes through several stages of metamorphisms depending on temperature, moisture, compaction, wind drift, and interactions with the underlaying surface or vegetation (e.g. Colbeck, 1982; Sturm et al., 2001). Due to these processes, the thermal conductivity of the snow cover can change by an order of magnitude. Parameterizations of snow thermal properties (e.g. Sturm et al., 1997) have not been extensively validated for arctic regions and thus involve large uncertainties. The performed sensitivity tests are based on reported variabilities of snow thermal properties. The resulting uncertainty in the modeled soil temperature clearly demonstrate the large impact of the snow properties on the thermal state of permafrost. This is not only critical for satellite-based permafrost modeling but involves permafrost modeling in general. A very recent study demonstrates that the oversimplification of the snow thermal properties in climate models strongly impacts the representation of permafrost and the related soil-biological processes (Gouttevin et al., 2012). An oversimplified snow cover parameterization becomes even more problematic as observations indicate that the arctic snow cover has changed strongly over the last decades and is expected to change even more pronounced in the future (Callaghan et al., 2011; Derksen and Brown, 2012). 
The performed sensitivity analysis takes into account a wide range of soil types ranging from medium-dry organic soils to water/ice saturated mineral soils. Within the applied model, this leads to strong variations in the soil thermal properties of the upper meters (cp. Sect.3.5). The large impact of the thermal conductivity of the uppermost organic soil layer on the regional climate and the thermal state of permafrost has been demonstrated in several studies (e.g. Rinke et al., 2008; Koven et al., 2009; Wisser et al., 2011). However, our results show that the impact of uncertainties in the soil thermal properties is largely overruled by the impact of uncertainties in the snow thermal properties. This result can be considered valid for landscapes that feature comparable subsurface and climate conditions and where similar assumptions of uncertainty are applicable.

In contrast to the thermal state of permafrost which is almost entirely governed by the snow cover, the active layer dynamic is mainly determined by the soil composition. The uncertainty in modeled thaw depth is clearly reduced when some knowledge about subsurface properties is available. This is especially true for the soil water or ice content which mainly determines the thaw depth. The use of further satellite products such as surface soil moisture (e.g. Wagner et al., 2007), surface wetness classifications (e.g. Muster et al., 2012), and freeze-thaw status (e.g. Bartsch et al., 2007) could help to reduce the uncertainties in thaw depth simulations. However, the robustness of the active layer dynamics towards uncertainties in the thermal snow properties is misleading. The thermal state of permafrost and the active layer dynamics are decoupled due to the very cold permafrost temperatures. Previous studies show that due to the cold conditions, a large fraction of the summertime ground heat flux is attributed to soil warming and a relatively constant fraction is consumed by the thawing of ground ice (Langer et al., 2011b). However, this could be different in the case of warmer permafrost conditions when most of the ground heat flux can be used for thawing (Yershov, 1998). Thus, a correct representation of the snow cover becomes critical for active layer modeling when climate warming has potentially the greatest impact on the thaw depth. The results of this study clearly demonstrate that large challenges remain for operational permafrost modeling based on satellite data especially in terms of snow cover forcing and parameterization. Furthermore, we would like to point out, though, that the results of this study are only applicable for regions with climate forcing and soil conditions similar to those at the of study site in NE Siberia. In addition, the impact of surface heterogeneities such as ponds or lakes on the thermal ground regime 
is not accounted for and heat transfer due to soil water convection is not included. Thus, further validation studies should be performed for a range of different climate conditions and landscape types before compiling an operational product. In addition, further model development is necessary in order to represent surface heterogeneities.

\section{Conclusions}

This study highlights the potential of permafrost monitoring using readily available remote sensing products. A thermal permafrost model enables reconstruction of the thermal state of the subsurface, which is not directly accessible through remote sensing. The scheme was able to reproduce the small warming of permafrost temperatures of about $1^{\circ} \mathrm{C}$ that has been measured at about $10 \mathrm{~m}$ depth over the past 5 years at the study site. The thermal properties of the snow pack, and particularly its thermal conductivity, constitute the largest source of uncertainty.

- The main features of permafrost dynamics, such as the inter-annual variations in thaw depth and the decadal warming trend, can be modeled from satellite data if the snow properties and soil compositions are known.

- The accuracy of land surface temperature forcing obtained from MODIS LST allows permafrost modeling with uncertainty ranges of less than $\pm 2{ }^{\circ} \mathrm{C}$ in temperature and $\pm 3 \mathrm{~cm}$ in thaw depth. These uncertainties are found to be much smaller than uncertainties induced by other factors such as SWE forcing and the thermal properties of the snow cover.

- The accuracy of GlobSnow SWE data appears to be adequate for representing the evolution of the snow depth with an accuracy better than $\pm 5 \mathrm{~cm}$, provided that calibration data are available. This accuracy allows permafrost modeling with a temperature uncertainty of less than $\pm 3^{\circ} \mathrm{C}$. However, the specified accuracy of the GlobSnow product would lead to large uncertainties of more than $\pm 5^{\circ} \mathrm{C}$.

- The largest uncertainties in permafrost modeling are induced by unknown thermal properties of the snow cover. Reliable permafrost modeling is not feasible in the absence of information on local snow cover characteristics. 
- Uncertainties in modeling the active layer dynamics are largely attributed to uncertainties in soil compositions, especially the soil water/ice content. In the worst case setting for the soil composition, the thaw depth can be reproduced with an uncertainty of about $\pm 15 \mathrm{~cm}$.

This permafrost monitoring scheme could be operationalized for permafrost monitoring on a pan-arctic scale, provided the range of uncertainties imposed by the model parameters and the available data are acceptable.

\section{Acknowledgements}

We thank Günther Stoof, Waldemar Schneider and our Russian partners at AARI for the technical and logistical support of our field work. We gratefully acknowledge the financial support by the Helmholtz Association through a grant (VH-NG 203) awarded to Julia Boike. Furthermore, the authors acknowledge the financial support by the European Union FP7-ENV project PAGE21 under contract number GA282700. We also like to thank Joel Rowland and one anonymous reviewer for the very constructive comments which helped to improve our manuscript.

\section{Appendix A. Settings for Monte-Carlo simulations}




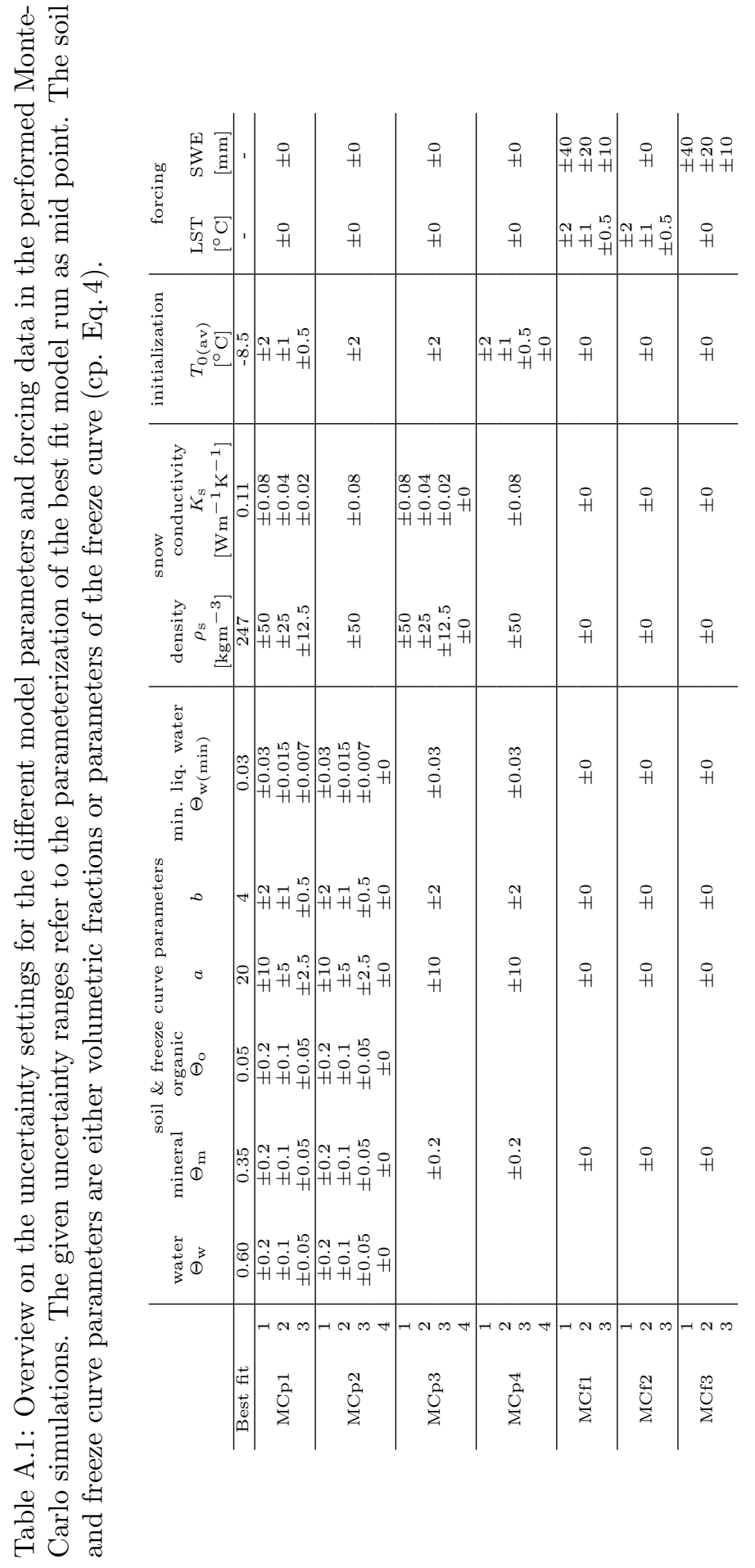




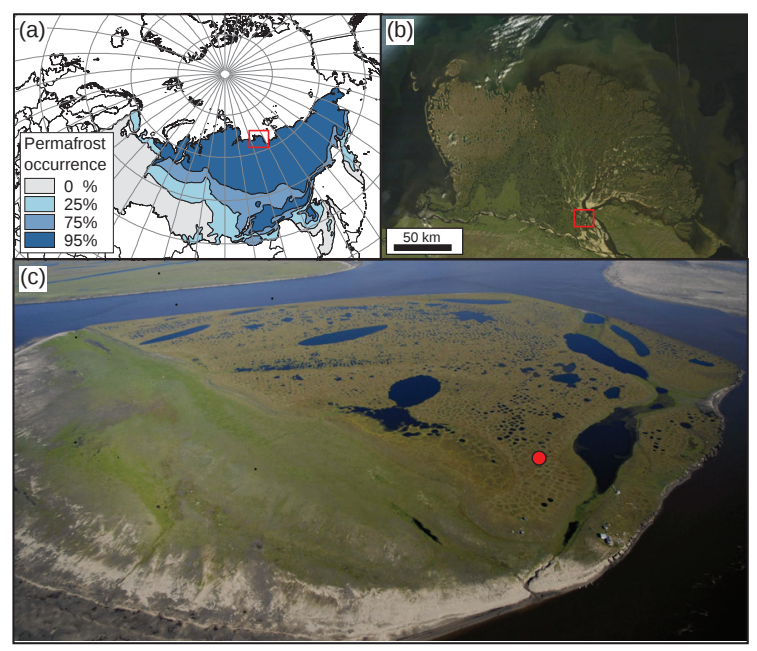

Figure 1: Location of the validation site on Samoylov Island. (a) Extent of permafrost in Russia with the location of the Lena River Delta marked with a red box (after Kotlyakov and Khromova, 2002). (b) MODIS (Terra) satellite image of the Lena River Delta obtained in August 2012 (NASA, 2012). (c) Aerial photograph of Samoylov Island featuring a surface area of about $4.5 \mathrm{~km}^{2}$. The location of the measurement site is marked with a red dot. 


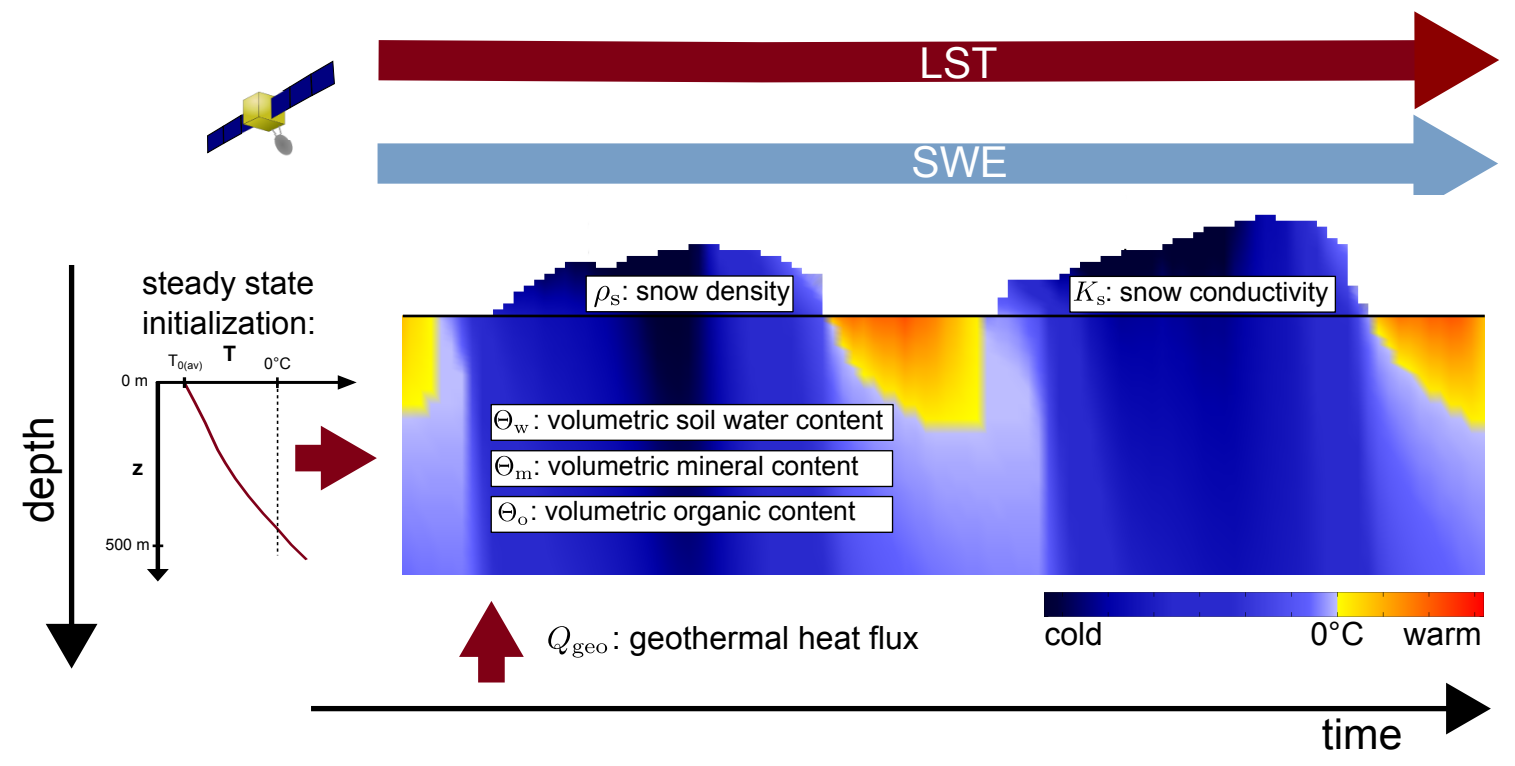

Figure 2: Scheme of the applied permafrost model with employed parameters. During the target period from 2002 to 2011, the model is forced solely by the MODIS LST, MODIS SCF, and GlobSnow SWE products. The model is run for 20 year spin-up period (19822001) prior to the target period during which the LST forcing is obtained from reanalysis data (ERA-Interim). 

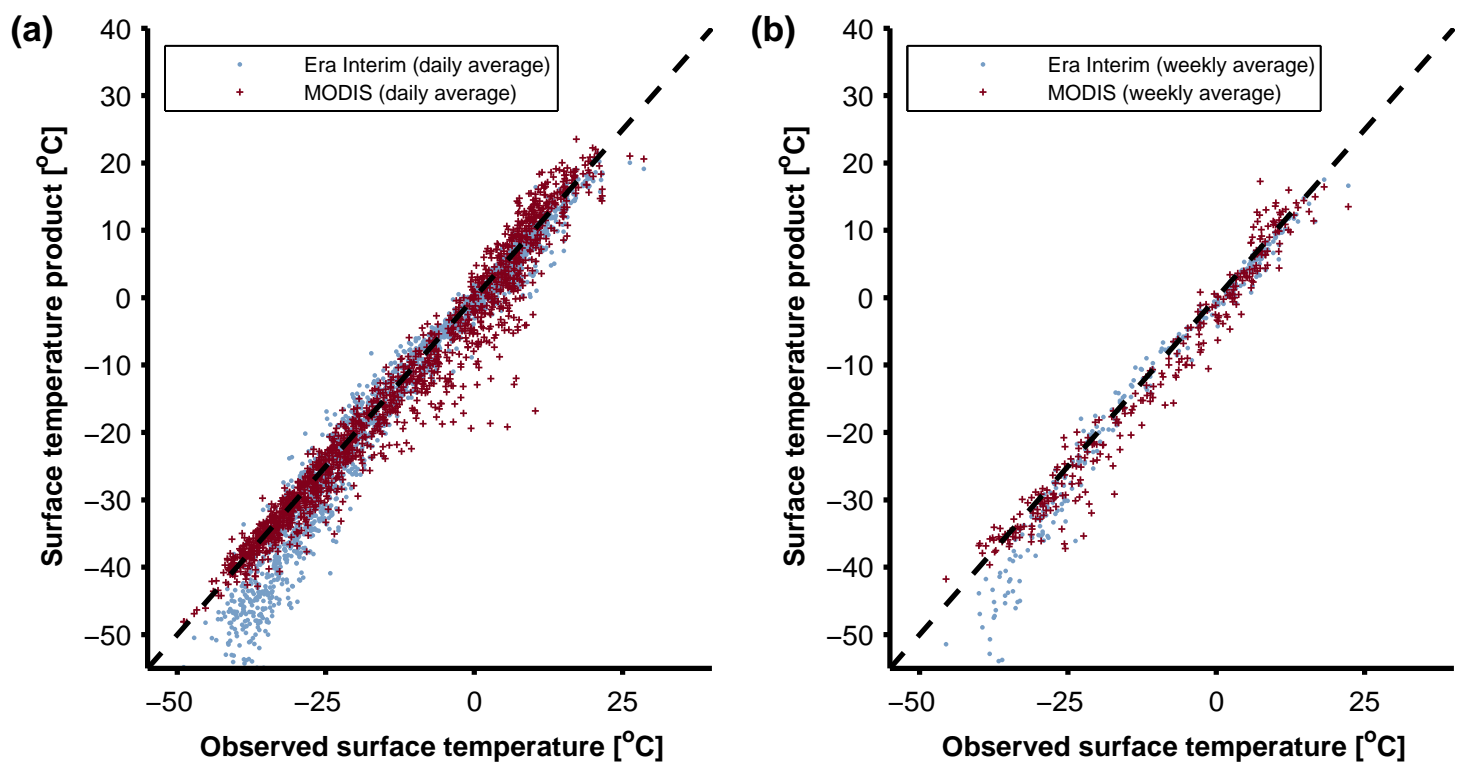

Figure 3: Comparison of daily (a) and weekly (b) surface temperature averages measured at the Samoylov field site with MODIS LST (MOD11A1, MYD11A1) and ERA-Interim LST values. The comparison includes field measurements from 2002 to 2011. 


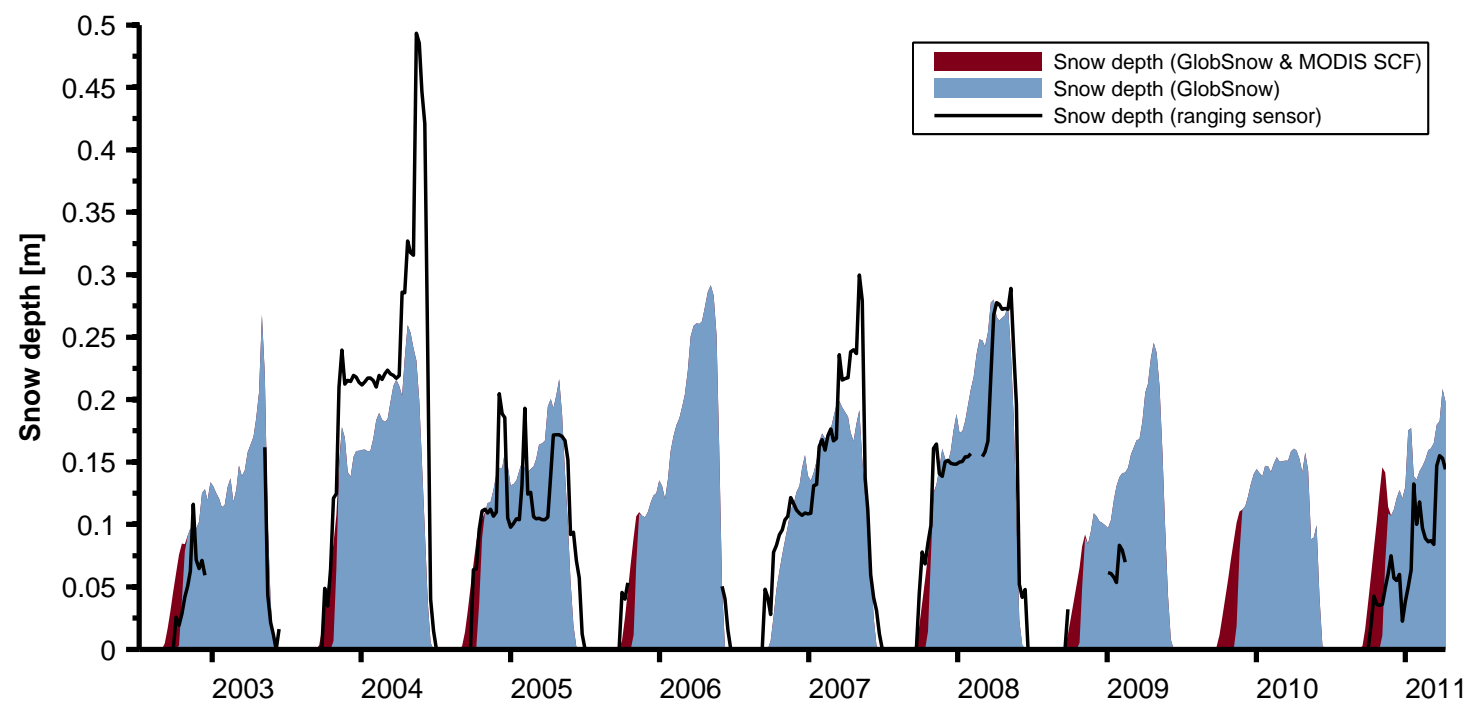

Figure 4: Snow depth evolution obtained from in situ measurements and GlobSnow SWE assuming a constant snow density of approximately $250 \mathrm{kgm}^{-3}$. 
(a)
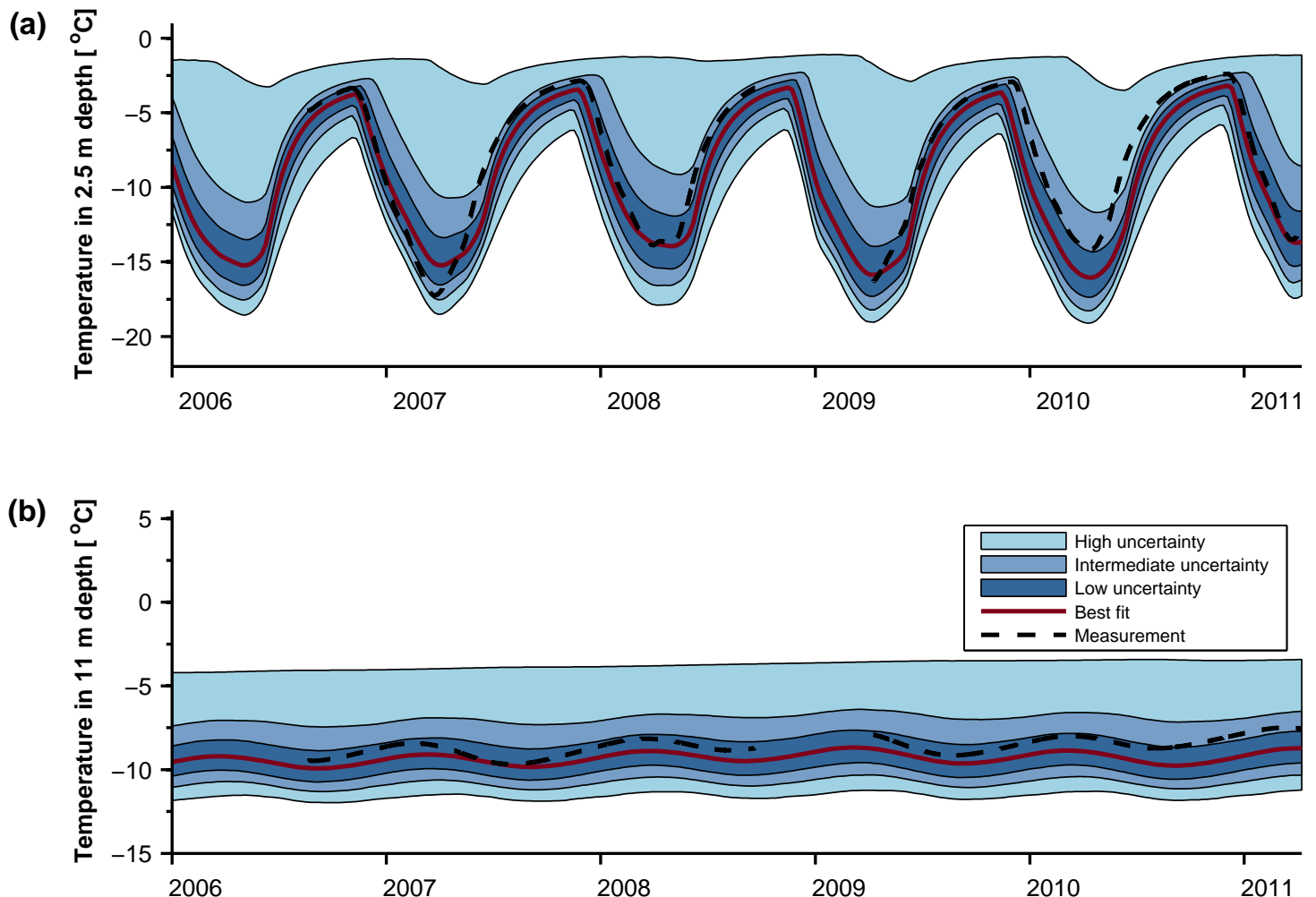

Figure 5: Comparing the results of the MCp1 (Tab. A.1) simulations with in-situ temperature measurements at (a) $2.5 \mathrm{~m}$ depth and (b) $11 \mathrm{~m}$ depth. The shaded areas illustrate the ranges of the resulting temperature distributions. 


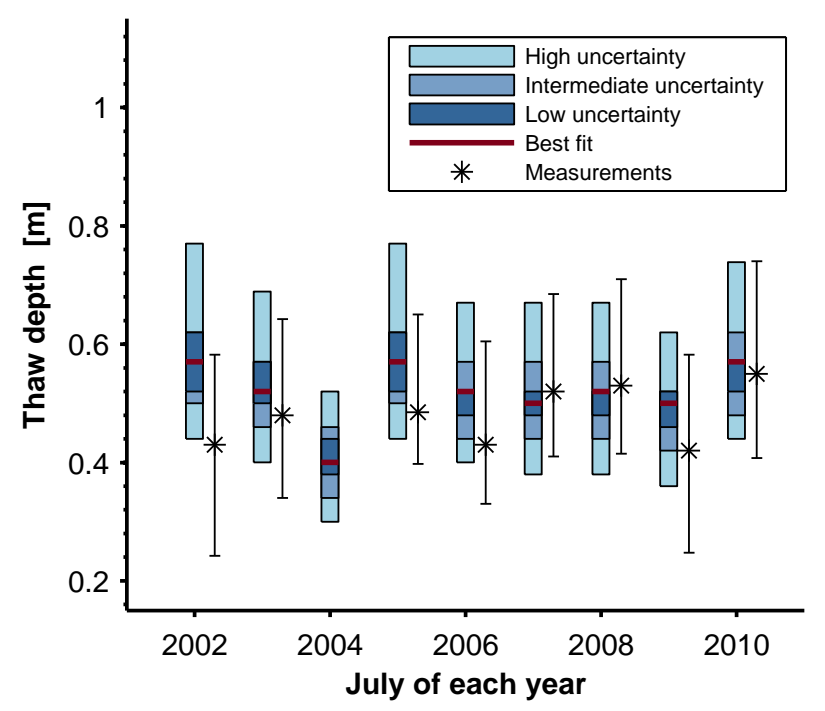

Figure 6: Measured versus modeled thaw depths at the end of July. The spatial variability of thaw depths at the study site are illustrated by the whiskers. The shaded bars show the ranges of thaw depths as resulted from the MCp1 simulations (Tab. A.1). 

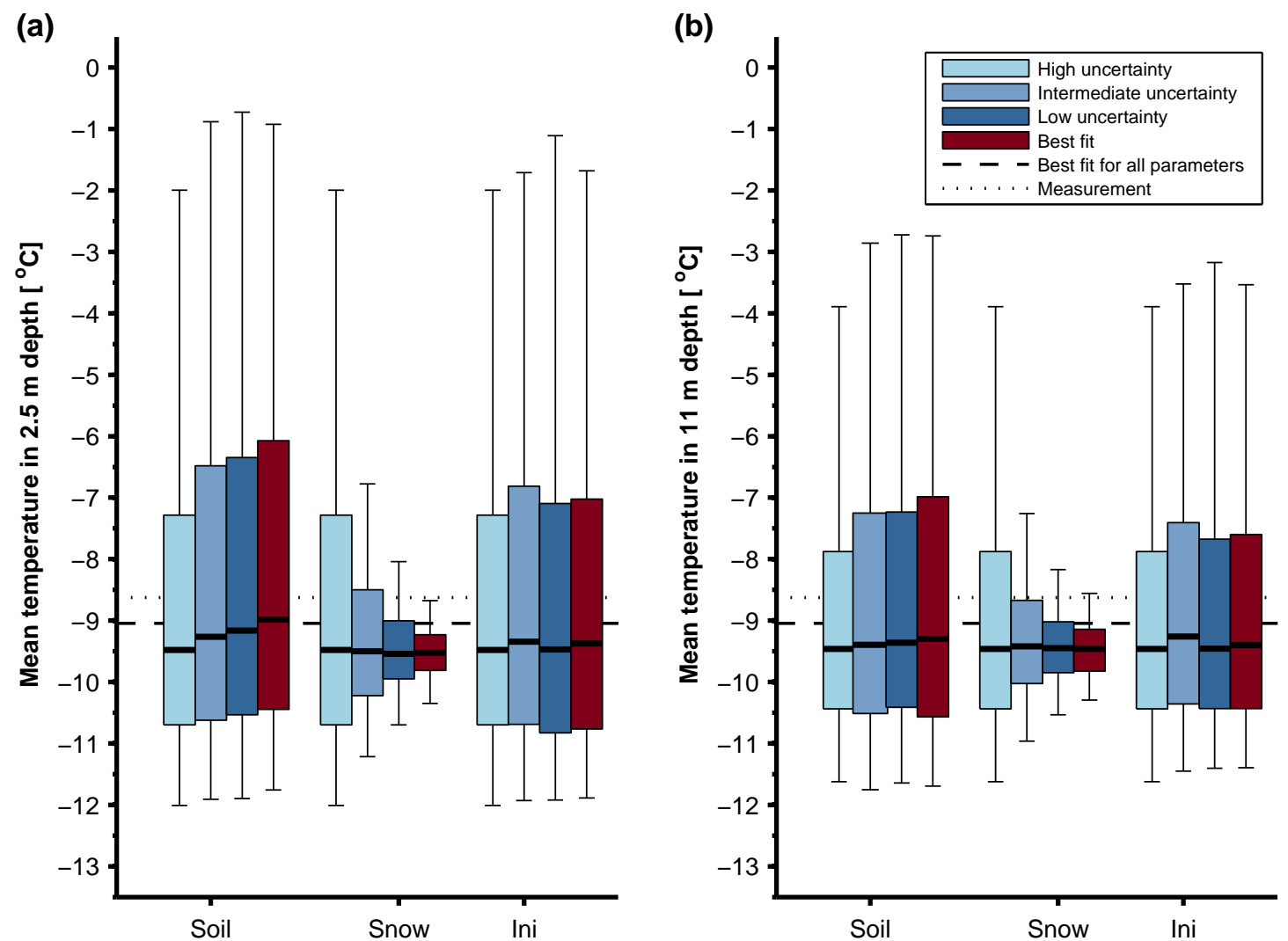

Figure 7: Uncertainty distributions of average permafrost temperatures modeled for a) $2.5 \mathrm{~m}$ and b) $11 \mathrm{~m}$ depth with different uncertainties on the soil, snow, and initialization (Ini) parameters (cp. MCp2-4 Tab. A.1). The permafrost temperatures are averaged over the validation period during which borehole temperature data are available. The shaded bares represent the quartile and the whiskers the range of the resulting temperature distributions. 


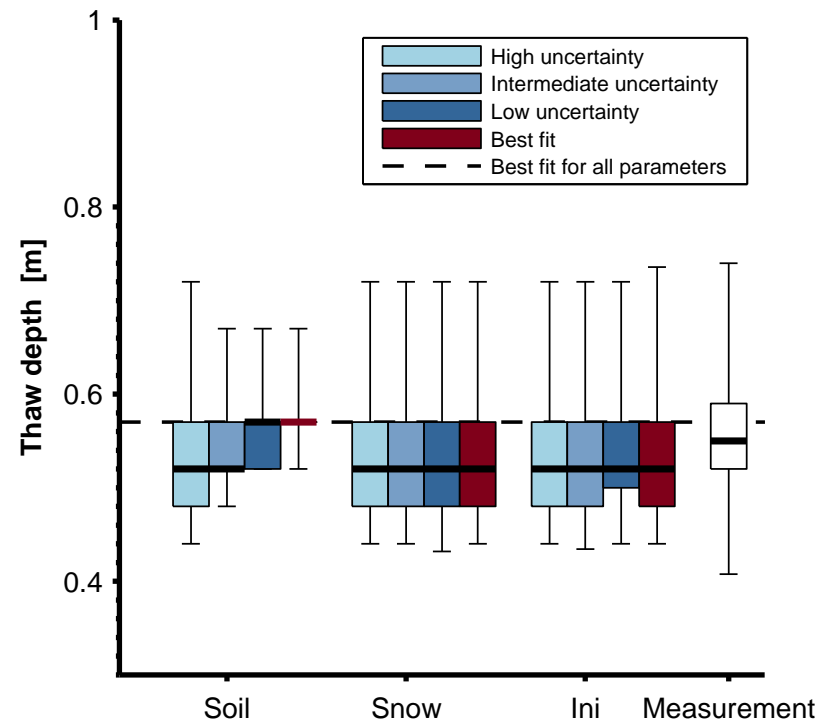

Figure 8: Uncertainties in modeled thaw depth associated with different ranges of uncertainty on the soil, snow, and initialization (Ini) parameters (cp. MCp2-4 Tab. A.1). The shown data depict maximum thaw depth in August 2010. The range of the thaw depth measurements reflects the spatial variability. The bars and whiskers represent the quartile and range of the thaw depth distributions. 

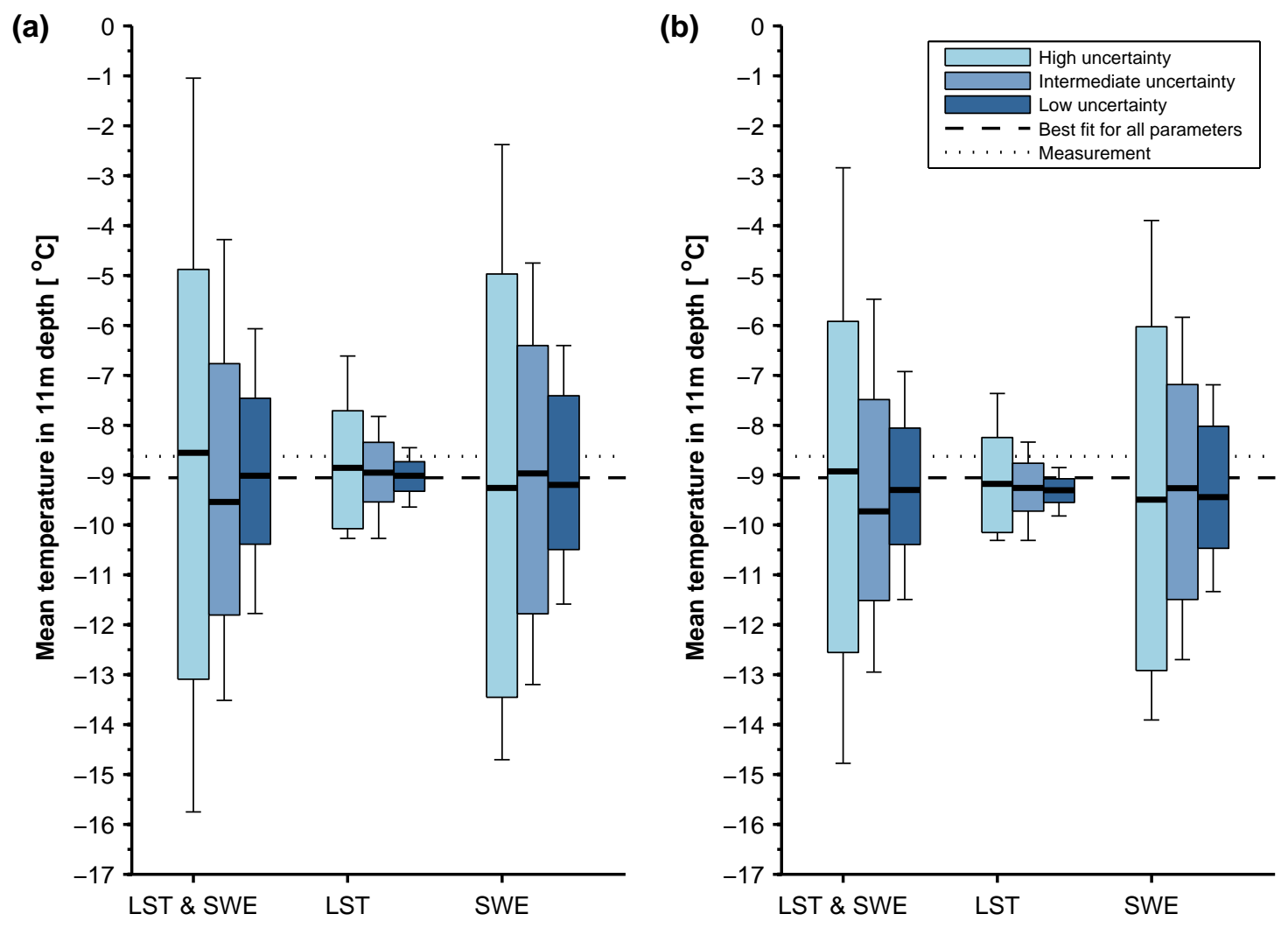

Figure 9: Uncertainty distributions of average permafrost temperatures modeled for a) $2.5 \mathrm{~m}$ and b) $11 \mathrm{~m}$ depth with different assumptions on accuracy in model forcing (cp. MCf1-3 Tab. A.1). The permafrost temperatures are averaged over the validation period during which borehole temperature data are available. 


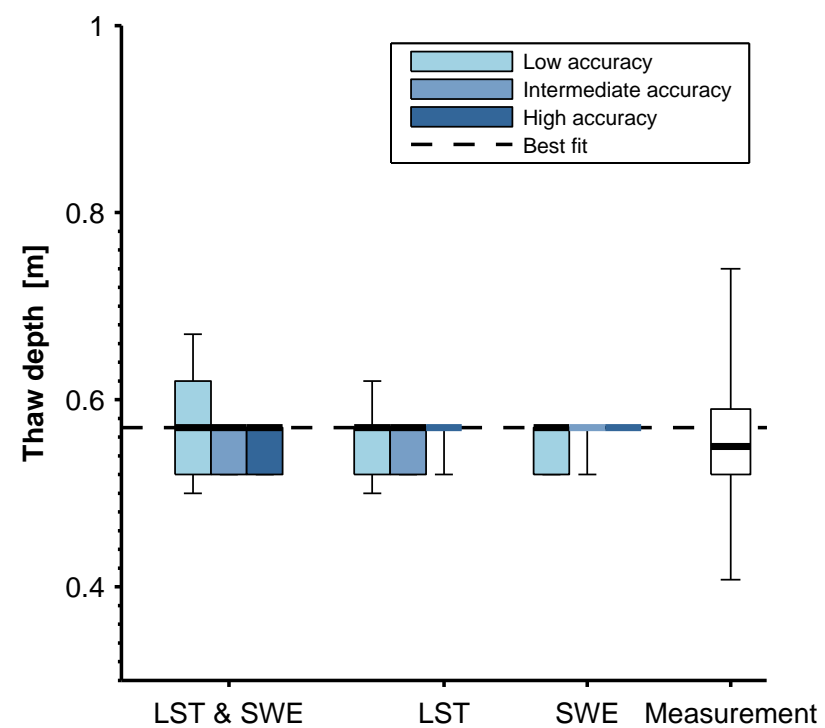

Figure 10: Uncertainties in modeled thaw depth associated with different levels of accuracy in model forcing (cp. MCf1-3 Tab. A.1). The shown data depict maximum thaw depth in August 2010. The range of the thaw depth measurements reflects the spatial variability. 


\section{References}

ACIA, 2004. Impacts of a Warming Arctic - Arctic Climate Impact Assessment. Vol. 1. Cambridge University Press, Cambridge, UK.

Åkerman, H. J., Johansson, M., 2008. Thawing permafrost and thicker active layers in sub-Arctic Sweden. Permafrost and Periglacial Processes 19 (3), 279-292.

AMAP, 2011. Snow, water, ice and permafrost in the Arctic (SWIPA). Oslo: Arctic Monitoring and Assessment Programme (AMAP).

Armstrong, R., Brodzik, M., 2001. Recent Northern Hemisphere snow extent: A comparison of data derived from visible and microwave satellite sensors. Geophysical Research Letters 28 (19), 3673-3676.

Bartsch, A., Kidd, R., Wagner, W., Bartalis, Z., 2007. Temporal and spatial variability of the beginning and end of daily spring freeze/thaw cycles derived from scatterometer data. Remote Sensing of Environment 106 (3), 360-374.

Boike, J., Kattenstroth, B., Abramova, K., Bornemann, N., Chetverova, A., Minke, M., Muster, S., Piel, K., Pfeiffer, E., Stoof, G., et al., 2012a. Baseline characteristics of climate, permafrost, and land cover from a new permafrost observatory in the Lena River Delta, Siberia (1998-2011). Biogeosciences Discussions 9, 13627-13684.

Boike, J., Langer, M., Lantuit, H., Muster, S., Roth, K., Sachs, T., Overduin, P., Westermann, S., McGuire, A., 2012b. Permafrost - Physical Aspects, Carbon Cycling, Databases and Uncertainties. In: Lal, R., Lorenz, K., Hüttl, R. F., Schneider, B. U., von Braun, J. (Eds.), Recarbonization of the Biosphere. Springer Netherlands, pp. 159-185.

Boike, J., Wille, C., Abnizova, A., 2008. Climatology and summer energy and water balance of polygonal tundra in the Lena River Delta, Siberia. Journal of Geophysical Research-Biogeosciences 113 (G3), G03025.

Callaghan, T., Johansson, M., Brown, R., Groisman, P., Labba, N., Radionov, V., Bradley, R., Blangy, S., Bulygina, O., Christensen, T., et al., 2011. Multiple effects of changes in Arctic snow cover. AMBIO: A Journal of the Human Environment 40, 32-45. 
Campbell, G., Jungbauer Jr, J., Bidlake, W., Hungerford, R., 1994. Predicting the effect of Temperature on Soil Thermal Conductivity. Soil Science 158 (5), 307-313.

Colbeck, S., 1982. An overview of seasonal snow metamorphism. Reviews of Geophysics and Space Physics 20 (1), 45-61.

De Vries, D., 1952. The thermal conductivity of soil. Mededelingen van de Landbouwhogeschool te Wageningen 52 (1), 1-73.

Dee, D., Uppala, S., Simmons, A., Berrisford, P., Poli, P., Kobayashi, S., Andrae, U., Balmaseda, M., Balsamo, G., Bauer, P., et al., 2011. The ERAInterim reanalysis: Configuration and performance of the data assimilation system. Quarterly Journal of the Royal Meteorological Society 137 (656), $553-597$.

Derksen, C., Brown, R., 2012. Spring snow cover extent reductions in the 2008-2012 period exceeding climate model projections. Geophysical Research Letters 39 (19).

Derksen, C., Toose, P., Lemmetyinen, J., Pulliainen, J., Langlois, A., Rutter, N., Fuller, M., 2011. Evaluation of passive microwave brightness temperature simulations and snow water equivalent retrievals through a winter season. Remote Sensing of Environment 117, 236-248.

Derksen, C., Walker, A., Goodison, B., 2005. Evaluation of passive microwave snow water equivalent retrievals across the boreal forest/tundra transition of western Canada. Remote Sensing of Environment 96 (3), 315-327.

Foster, J., Sun, C., Walker, J., Kelly, R., Chang, A., Dong, J., Powell, H., 2005. Quantifying the uncertainty in passive microwave snow water equivalent observations. Remote Sensing of Environment 94 (2), 187-203.

Frei, A., Tedesco, M., Lee, S., Foster, J., Hall, D., Kelly, R., Robinson, D., 2012. A review of global satellite-derived snow products. Advances in Space Research 50, 1007-1029.

Goodrich, L., 1982. The influence of snow cover on the ground thermal regime. Canadian Geotechnical Journal 19 (4), 421-432. 
Gouttevin, I., Menegoz, M., Dominé, F., Krinner, G., Koven, C., Ciais, P., Tarnocai, C., Boike, J., 2012. How the insulating properties of snow affect soil carbon distribution in the continental pan-Arctic area. Journal of Geophysical Research 117 (G2), G02020.

Grigoriev, M., Imaev, V., Imaeva, L., Kozmin, B., Kunitzkiy, V., Lationov, A., et al., 1996. Geology, seismicity and cryogenic processes in the arctic areas of Western Yakutia. Yakut Scientific Centre SD RAS, Yakutsk, 84.

Grigoriev, N., 1960. The temperature of permafrost in the Lena delta basin - deposit conditions and properties of the permafrost in Yakutia. Yakutsk, Ch. 2, pp. 97-101, in Russian.

Hachem, S., Allard, M., Duguay, C., 2009. Using the MODIS land surface temperature product for mapping permafrost: an application to northern Québec and Labrador, Canada. Permafrost and Periglacial Processes 20 (4), 407-416.

Hachem, S., Duguay, C., Allard, M., 2012. Comparison of MODIS-derived land surface temperatures with ground surface and air temperature measurements in continuous permafrost terrain. The Cryosphere 6, 51-69.

Hall, D., 1988. Assessment of polar climate change using satellite technology. Reviews of Geophysics 26 (1), 26-39.

Hall, D., Nghiem, S., Schaaf, C., DiGirolamo, N., Neumann, G., 2009. Evaluation of surface and near-surface melt characteristics on the Greenland ice sheet using MODIS and QuikSCAT data. J. Geophys. Res 114, F04006.

Hall, D., Riggs, G., 2007. Accuracy assessment of the MODIS snow products. Hydrological Processes 21 (12), 1534-1547.

Hall, D., Riggs, G., Salomonson, V., DiGirolamo, N., Bayr, K., 2002. MODIS snow-cover products. Remote sensing of Environment 83 (1), 181-194.

Jiang, Y., Zhuang, Q., O’Donnell, J., 2012. Modeling thermal dynamics of active layer soils and near-surface permafrost using a fully coupled water and heat transport model. Journal of Geophysical Research 117 (D11), D11110. 
Koenig, L., Hall, D., 2010. Comparison of satellite, thermochron and air temperatures at Summit, Greenland, during the winter of 2008/09. Journal of Glaciology 56 (198), 735-741.

Kotlyakov, V., Khromova, T., 2002. Land Resources of Russia - Maps of Permafrost and Ground Ice. Boulder, Colorado USA: National Snow and Ice Data Center.

Koven, C., Friedlingstein, P., Ciais, P., Khvorostyanov, D., Krinner, G., Tarnocai, C., 2009. On the formation of high-latitude soil carbon stocks: Effects of cryoturbation and insulation by organic matter in a land surface model. Geophysical Research Letters 36 (21), L21501.

Kutzbach, L., Wagner, D., Pfeiffer, E., 2004. Effect of microrelief and vegetation on methane emission from wet polygonal tundra, Lena Delta, Northern Siberia. Biogeochemistry 69 (3), 341-362.

Lachenbruch, A., 1962. Mechanics of thermal contraction cracks and icewedge polygons in permafrost. No. 70-72. Geological Society of America.

Langer, M., Westermann, S., Boike, J., 2010. Spatial and temporal variations of summer surface temperatures of wet polygonal tundra in Siberia - implications for MODIS LST based permafrost monitoring. Remote Sensing of Environment 114 (9), 2059-2069.

Langer, M., Westermann, S., Muster, S., Piel, K., Boike, J., 2011a. The surface energy balance of a polygonal tundra site in northern Siberia Part 1: Spring to fall. The Cryosphere 5 (1), 151-171.

Langer, M., Westermann, S., Muster, S., Piel, K., Boike, J., 2011b. The surface energy balance of a polygonal tundra site in northern Siberia Part 2: Winter. The Cryosphere 5, 509-524.

Larsen, P., Goldsmith, S., Smith, O., Wilson, M., Strzepek, K., Chinowsky, P., Saylor, B., 2008. Estimating future costs for Alaska public infrastructure at risk from climate change. Global Environmental Change 18 (3), $442-457$.

Liu, Y., Ackerman, S., Maddux, B., Key, J., Frey, R., 2010. Errors in cloud detection over the Arctic using a satellite imager and implications for observing feedback mechanisms. Journal of Climate 23 (7), 1894-1907. 
Luojus, K., Pulliainen, J., Takala, M., Derksen, C., Rott, H., Nagler, T., Solberg, R., Wiesmann, A., Metsamaki, S., Malnes, E., et al., 2010. Investigating the feasibility of the GlobSnow snow water equivalent data for climate research purposes. In: Geoscience and Remote Sensing Symposium (IGARSS), 2010 IEEE International. IEEE, pp. 4851-4853.

Marchenko, S., Hachem, S., Romanovsky, V., Duguay, C., 2009. Permafrost and Active Layer Modeling in the Northern Eurasia using MODIS Land Surface Temperature as an input data. Geophysical Research Abstracts 11, EGU2009-11077.

Mooney, P., Mulligan, F., Fealy, R., 2011. Comparison of ERA-40, ERAInterim and NCEP/NCAR reanalysis data with observed surface air temperatures over Ireland. International Journal of Climatology 31 (4), 545557.

Muster, S., Langer, M., Heim, B., Westermann, S., Boike, J., 2012. Subpixel heterogeneity of ice-wedge polygonal tundra: a multi-scale analysis of land cover and evapotranspiration in the Lena River Delta, Siberia. Tellus B 64 .

NASA, 2012. The Lena River Delta. NASA/GSFC/Earth Science Data and Information System (ESDIS), http://earthdata.nasa.gov/data/nrtdata/rapid-response.

Panda, S., Prakash, A., Solie, D., Romanovsky, V., Jorgenson, M., 2010. Remote sensing and field-based mapping of permafrost distribution along the Alaska Highway corridor, interior Alaska. Permafrost and Periglacial Processes 21 (3), 271-281.

Pollack, H., Hurter, S., Johnson, J., 1993. Heat flow from the Earth's interior: analysis of the global data set. Reviews of Geophysics 31 (3), 267-280.

Rignot, E., Thomas, R., 2002. Mass balance of polar ice sheets. Science 297 (5586), 1502-1506.

Rinke, A., Kuhry, P., Dethloff, K., 2008. Importance of a soil organic layer for Arctic climate: A sensitivity study with an Arctic RCM. Geophysical Research Letters 35 (13), L13709. 
Romanovsky, V., Osterkamp, T., 2000. Effects of unfrozen water on heat and mass transport processes in the active layer and permafrost. Permafrost and Periglacial Processes 11 (3), 219-239.

Salomonson, V., Appel, I., 2004. Estimating fractional snow cover from MODIS using the normalized difference snow index. Remote Sensing of Environment 89 (3), 351-360.

Schwamborn, G., Rachold, V., Grigoriev, M., 2002. Late Quaternary sedimentation history of the Lena Delta. Quaternary International 89 (1), $119-134$.

Screen, J., Simmonds, I., 2011. Erroneous Arctic temperature trends in the ERA-40 reanalysis: a closer look. Journal of Climate 24 (10), 2620-2627.

Shampine, L., Reichelt, M., 1997. The matlab ode suite. SIAM journal on scientific computing 18 (1), 1-22.

Simmons, A., Willett, K., Jones, P., Thorne, P., Dee, D., 2010. Lowfrequency variations in surface atmospheric humidity, temperature, and precipitation: Inferences from reanalyses and monthly gridded observational data sets. Journal of Geophysical Research 115 (D1), D01110.

Smith, S., Romanovsky, V., Lewkowicz, A., Burn, C., Allard, M., Clow, G., Yoshikawa, K., Throop, J., 2010. Thermal state of permafrost in North America: a contribution to the International Polar Year. Permafrost and Periglacial Processes 21 (2), 117-135.

Stow, D., Hope, A., McGuire, D., Verbyla, D., Gamon, J., Huemmrich, F., Houston, S., Racine, C., Sturm, M., Tape, K., et al., 2004. Remote sensing of vegetation and land-cover change in Arctic Tundra Ecosystems. Remote Sensing of Environment 89 (3), 281-308.

Stroeve, J., Box, J., Haran, T., 2006. Evaluation of the MODIS (MOD10A1) daily snow albedo product over the Greenland ice sheet. Remote Sensing of Environment 105 (2), 155-171.

Stroeve, J., Holland, M., Meier, W., Scambos, T., Serreze, M., 2007. Arctic sea ice decline: Faster than forecast. Geophysical Research Letters 34 (9), 9501. 
Sturm, M., Holmgren, J., König, M., Morris, K., 1997. The thermal conductivity of seasonal snow. Journal of Glaciology 43 (143), 26-41.

Sturm, M., Holmgren, J., McFadden, J., Liston, G., Chapin III, F., Racine, C., 2001. Snow-shrub interactions in Arctic tundra: a hypothesis with climatic implications. Journal of Climate 14 (3), 336-344.

Szczypta, C., Calvet, J., Albergel, C., Balsamo, G., Boussetta, S., Carrer, D., Lafont, S., Meurey, C., 2011. Verification of the new ECMWF ERAInterim reanalysis over France. Hydrology and Earth System Sciences 15, 647-666.

Takala, M., Luojus, K., Pulliainen, J., Derksen, C., Lemmetyinen, J., Karna, J., Koskinen, J., Bojkov, B., 2011. Implementing hemispherical snow water equivalent product assimilating weather station observations and spaceborne microwave data. In: Geoscience and Remote Sensing Symposium (IGARSS), 2011 IEEE International. IEEE, pp. 3768-3771.

Van Everdingen, R., 1998. Multi-Language Glossary of Permafrost and Related Ground-Ice Terms, revised May 2005. National Snow and Ice Data Center/World Data Center for Glaciology, Boulder, CO.

Wagner, W., Naeimi, V., Scipal, K., de Jeu, R., Martínez-Fernández, J., 2007. Soil moisture from operational meteorological satellites. Hydrogeology Journal 15 (1), 121-131.

Wan, Z., Dozier, J., 1996. A generalized split-window algorithm for retrieving land-surfacetemperature from space. IEEE Transactions on geoscience and remote sensing 34 (4), 892-905.

Wania, R., Ross, I., Prentice, I., 2009a. Integrating peatlands and permafrost into a dynamic global vegetation model: 1. Evaluation and sensitivity of physical land surface processes. Global Biogeochemical Cycles 23 (3), GB3014.

Wania, R., Ross, I., Prentice, I., 2009b. Integrating peatlands and permafrost into a dynamic global vegetation model: 2. Evaluation and sensitivity of vegetation and carbon cycle processes. Global Biogeochemical Cycles 23, 3015 . 
Weismüller, J., Wollschläger, U., Boike, J., Pan, X., Yu, Q., Roth, K., 2011. Modeling the thermal dynamics of the active layer at two contrasting permafrost sites on Svalbard and on the Tibetan Plateau. The Cryosphere, Volume 5, Issue 3, 2011, pp. 741-757 5, 741-757.

Westermann, S., Boike, J., Langer, M., Schuler, T., Etzelmüller, B., 2011a. Modeling the impact of wintertime rain events on the thermal regime of permafrost. The Cryosphere 5, 1697-1736.

Westermann, S., Langer, M., Boike, J., 2011b. Spatial and temporal variations of summer surface temperatures of high-arctic tundra on SvalbardImplications for MODIS LST based permafrost monitoring. Remote Sensing of Environment 115 (3), 908-922.

Westermann, S., Langer, M., Boike, J., 2012. Systematic bias of average winter-time land surface temperatures inferred from MODIS at a site on Svalbard, Norway. Remote Sensing of Environment 118, 162-167.

Wisser, D., Marchenko, S., Talbot, J., Treat, C., Frolking, S., 2011. Soil temperature response to 21st century global warming: the role of and some implications for peat carbon in thawing permafrost soils in North America. Earth System Dynamics 2, 1-18.

Yershov, E., 1998. General geocryology. Cambridge Univ Press.

Zhang, T., 2005. Influence of the seasonal snow cover on the ground thermal regime: An overview. Reviews of Geophysics 43 (4).

Zubrzycki, S., Kutzbach, L., Desyatkin, A., Pfeiffer, E., 2012. Soil Organic Carbon Stocks in Arctic Deltaic Sediments: Investigations in the Lena River Delta. In: EGU General Assembly Conference Abstracts. Vol. 14. p. 9866. 